\title{
Yield and Quality Potential of Anisia Bean (Phaseolus vulgaris) Varity
}

\author{
Costel VINATORU ${ }^{1)}$, Bianca ZAMFIR ${ }^{11}$, Camelia BRATU ${ }^{1)}$, Viorica LAGUNOVSCHI'), \\ Luminita Cârstea ${ }^{3)}$ \\ ${ }^{1)}$ Vegetable Research and Development Station Buzau, Romania; \\ 2) University of Agronomic Science and Veterinary Medicine, Bucharest,Romania; \\ 3) Institute for Vegetable Growing and Floriculture Vidra, Romania; \\ ${ }^{*}$ Corresponding author, e-mail: costel_vinatoru@yahoo.com
}

Bulletin UASVM Horticulture 72(1) / 2015

Print ISSN 1843-5254, Electronic ISSN 1843-5394

Doi:10.15835/buasvmcn-hort:10441

\begin{abstract}
Common bean is an economically, nutritionally, and socially important crop. In our country this species has tradition, is known as being present as cultivated crop since the 18th century. We have few Romanian approved creations in bean species. Local populations and foreign varieties were preferred to be introduced in crops. For these reasons, at V.R.D.S. Buzau appeared the necessity of completing the assortment of garden beans through a breeding programme released in 1996. Seed is a primary and essential starting point for a wide range of horticultural crops, including the majority of vegetables and many annual and biennial ornamentals. The study of the quantitative characters variability and correlation between them is very important for breeding process and conservative selection. The conservative selection scheme for each species it cannot be applied without knowing quantitative characters variability for each variety making easy the breeder activity in the selection process. Along with the culture introduction and conservative selection of the variety, a special attention was paid to maintaining the quantitative and qualitative characters variability limits focusing on assuring distinctibility, uniformity and stability. Romanian varieties deficit at these species imposed a special research program at Vegetable Research and Development Station Buzău. The breeding method used was individual selection after specific parameters, using the original material of local populations.
\end{abstract}

Keywords: breeding, crop, pod, Romanian assortment, selection.

\section{INTRODUCTION}

It is grown in distinct regions and different seasons around the world by subsistence level farmers with low-technology input as well as by farmers that use high input technologies. (Souza, 2013). Seed quality includes several factors; potential germination (including vigour), genetic quality, mechanical purityt and seeds free from seed pathogens and pests (Balkaya, 2007) Strategies employed by dry bean breeders to improve yield include early generation testing, ideotype breeding, selection for physiological efficiency, and selection based on genotypic performance and combining ability across gene pools of Phaseolus vulgaris. (Kelly, 1998).

\section{AIMS AND OBJECTIVES}

Establishment of production potential and quality of the yield obtained from garden beans variety obtained at V.R.D.S. Buzau.

\section{MATERIALS AND METHODS}

The breeding method used was individual selection after specific parameters, using the original material of local populations. To evaluate the genetic yield and quality potential of Anisia variety of bean, starting with 2011, annually comparative crops were established annually including 6 determined yellow podded varieties: Ioana (V.R.D.S. Buzau), Maxidor (control variant 1), Carson, Unidor, Oxyamidor and Goldestern. 
Tab. 1. Yield and quality data of studied varieties at S.C.D.L. Buzau 2011-2013.

\begin{tabular}{|c|c|c|c|c|c|c|c|c|c|c|c|}
\hline \multirow{3}{*}{ VARIANT } & \multirow{3}{*}{$\begin{array}{l}\text { YIELD } \\
(\%)\end{array}$} & \multicolumn{3}{|c|}{$\begin{array}{c}\text { Compared to Maxidor } \\
\text { (Marker 1) }\end{array}$} & \multicolumn{3}{|c|}{$\begin{array}{c}\text { Compared to average } \\
\text { (Marker 2) }\end{array}$} & \multicolumn{4}{|c|}{ Yield distribution on qualities } \\
\hline & & \multirow{2}{*}{$\begin{array}{l}\text { Relative } \\
\text { yield } \\
(\%)\end{array}$} & \multirow{2}{*}{$\begin{array}{c}\text { Marker } 1 \\
\text { difference } \\
\text { (t/ha) }\end{array}$} & \multirow{2}{*}{$\begin{array}{l}\text { Signi- } \\
\text { ficant }\end{array}$} & \multirow{2}{*}{$\begin{array}{l}\text { Relative } \\
\text { yield. } \\
(\%)\end{array}$} & \multirow{2}{*}{$\begin{array}{l}\text { Marker } 1 \\
\text { difference } \\
(\mathrm{t} / \mathrm{h})\end{array}$} & \multirow{2}{*}{$\begin{array}{l}\text { Signi- } \\
\text { ficant }\end{array}$} & \multirow{2}{*}{$\begin{array}{l}\text { Total } \\
\text { STAS } \\
(\%)\end{array}$} & \multicolumn{3}{|c|}{ Of which } \\
\hline & & & & & & & & & I (\%) & II (\%) & $\begin{array}{l}\text { below } \\
\text { STAS } \\
\end{array}$ \\
\hline ANISIA & 12.65 & 267 & +7.91 & $\mathrm{Xxx}$ & 152 & +4.31 & $\mathrm{Xxx}$ & 95.8 & 82.4 & 10.2 & 3.2 \\
\hline $\begin{array}{l}\text { MAXIDOR } \\
\text { (Marker) }\end{array}$ & 4.74 & 100 & - & - & 57 & -3.60 & 000 & 88.9 & 49.4 & 27.1 & 12.8 \\
\hline IOANA & 10.41 & 219 & +5.67 & $\mathrm{Xxx}$ & 125 & +2.07 & $\mathrm{Xxx}$ & 94.2 & 76.8 & 11.2 & 6.2 \\
\hline CARSON & 8.39 & 177 & +3.65 & $\mathrm{Xxx}$ & 100 & +0.05 & - & 91.4 & 63.4 & 18.4 & 9.6 \\
\hline UNIDOR & 6.22 & 131 & +1.48 & $\mathrm{Xx}$ & 75 & -2.12 & 000 & 87.8 & 48.5 & 28.1 & 11.2 \\
\hline OXYAMIDOR & 8.24 & 174 & +3.50 & $\mathrm{Xxx}$ & 99 & -0.11 & - & 91.4 & 53.7 & 25.9 & 11.8 \\
\hline GOLDESTERN & 7.78 & 164 & +3.04 & $\mathrm{xxx}$ & 93 & -0.56 & - & 88.5 & 40.3 & 39.7 & 8.5 \\
\hline \multicolumn{12}{|l|}{ Average $=8,34$} \\
\hline $\begin{array}{l}\text { Jote: } \text { DL. } 5 \%-0,86 \\
\text { DL. } 1 \%-1,16 \\
\text { DL } 0,1 \%-1,57\end{array}$ & & $\begin{array}{l}5 \%-0,76 \\
1 \%-1,02 \\
0,1 \%-1,\end{array}$ & & & & & & & & & \\
\hline
\end{tabular}

Tab. 2. The content of dry soluble matter, starch and sugar for all studied varieties.

\begin{tabular}{lccccccc}
\hline Analisis & Anisia & Maxidor & Ioana & Carson & Unidor & Oxyamidor & Goldestern \\
\hline Soluble dry matter \% & 2.31 & 1.91 & 2.35 & 1.76 & 2.15 & 2.28 & 2.12 \\
\hline Sugar \% & 9.2 & 7.8 & 8.7 & 9.3 & 8.1 & 6.9 & 7.4 \\
\hline Starch & 2.04 & 2.15 & 2.28 & 3.12 & 3.18 & 2.02 & 3.24 \\
\hline
\end{tabular}

\section{RESULTS AND DISCUSSION}

2013 year marked the consent and crop extension of Anisia variety of bean obtained at V.R.D.S. Buzau based on ISTIS evaluation. After 3 years of studying it in comparative crops with 6 top varieties, Anisia distinguished itself through superior quantitative and quality yield. Compared with control variant Maxidor , Anisia recorded 7.91 t/ha more, which means 267\% increase. Analyzing the main pods characteristics it was ascertained that regarding quality division Anisia recorded a STAS yield of $95.8 \%$, (Tab.1). The other studied varieties registered different yields year by year, below $10 \mathrm{t} / \mathrm{h}$. The average quality values show that Anisia registered a significantly increase yield compared to marker and total average yield of the others variants.

In what concerns the main chemical characteristics, Anisia distinguished itself by an increased dry matter by $9.5 \%$, a good sugar level, above $2.35 \%$ (Tab.2).

\section{CONCLUSION}

Anisia variety of bean obtained atV.R.D.S. Buzau demonstrated genetical superiority regarding yield and quality compared with Maxidor control variant and the other 6 studied varieties. The main objectives were reached: superior yield, of over 12 t/ha, superior quality yield and the enrichment of the Romanian assortment.

\section{REFERENCES}

1. Balkaya A., Odabas, S.(2007), The effects of sowing date and seed yield and quality of red podded bean cultivars, Acta Hort. ISHS.

2. Kelly JD, Kolkman JM, Schneider K (1998), Crop and soil sciences, Michigan, Euphytica, U.S.A.

3. Souza TLPO, Faleiro FG, Dessaunne SN, Paula-Junior TJ, Moreira MA, de Barros EG (2013), Tropical plant pathology, vol. 38, Epub, Brasilia. 